\title{
Insecticide Resistance-Susceptibility Tests with German Cockroaches (Blattella germanica Linnaeus) in Puerto Rico
}

\author{
J. Richard Gorham ${ }^{1}$ \\ INTRODUCTION AND OBJECTIVES
}

Besides being pests, cockroaches have been incriminated as actual or potential vectors of several pathogens of human diseases (3). ${ }^{2}$ The German cockroach in continental United States has developed resistance to several insecticides, especially the chlorinated hydrocarbons. This situation has recently been reviewed by Grayson (2).

The objective of this project was to determine the resistance-susceptibility status of a local strain of the German cockroach to several insecticides. No information of this sort for Puerto Rico has been published heretofore.

\section{MATERIALS AND METHODS}

Cockroaches from two laboratories in the School of Medicine, San Juan, P.R., were used to start colonies which were confined in glass carboys from which the tops had been removed. A thin layer of a 1:1 mixture of petrolatum and mineral oil painted around the rim of the culture jar kept the cockroaches from escaping the jar. The cockroaches were fed rat-food supplemented by dried brewer's yeast, bread, crackers, and occasionally a fragment of potato or lettuce. The colonies were started in the middle of August 1960, and the tests were carried out during February, March, and April of 1961. During the test period it was estimated that cockroaches of generations $\mathrm{F}_{3-6}$ were used. No attempt was made to keep the generations separate. Only adult cockroaches were used in the tests. When female cockroaches

${ }^{1}$ Permanent address: 211 West Church St., Xenia, Ohio, U.S. This project, supported in part by Graduate Training Grant 2E-15 (C2) from the National Institute of Allergy and Infectious Diseases, was carried out when the writer was a U.S. Public Health Service Postdoctoral Trainee in Medical Entomology in the Department of Medical Zoology, School of Medicine, School of Tropical Medicine, University of Puerto Rico, San Juan, P.R. I wish to thank Dr. Irving Fox, Training Grant Program Director in the Department of Medical Zoology, and Dr. José Oliver-González, Chairman of that Department, for their interest in this project. It was the writer's privilege to have the benefit of a critical review of the manuscript of this report by Drs. J. M. Grayson and D. G. Cochran of the Virginia Polytechnic Institute. The identification of the cockroach species was verified by Dr. Ashley B. Gurney of the Entomology Research Division, USDA. Miss Ileana García-Moll translated the Summary into Spanish.

2 Italic numbers in parentheses refer to Literature Cited, p. 225. 
were used, approximately half were capsulate (ootheca attached) and half were noncapsulate in any given replicate.

\section{L'T50 TESTS}

The procedure for the LT50 test for German cockroaches, as given by the Armed Forces Pest Control Board (1), was employed in the present study. That procedure is briefly summarized as follows: Into each of three pint glass jars were placed $2.5 \mathrm{ml}$. of the insecticide formulation. The jar was rotated gently so that the solution passed over all inner surfaces up to the neck. After the formulation dried, the inside surface of the neck of the bottle was painted with a petrolatum-mineral-oil mixturc. The test jars were prepared approximately 18 hours before the tests were initiated. Into a fourth jar, the control, were placed $2.5 \mathrm{ml}$. of acetone, which quickly dried as the jar was rotated. Ten adult cockroaches were placed in each of the jars and observations were made every half hour up to 5 hours, every hour up to 7 hours, then at 24 -hour intervals. After the first 24 hours a piece of potato was placed in each jar to provide food and water for the cockroaches.

\section{LC50 AND LC90 TESTS}

The LC50-90 test procedures varied from the LT50 technique in several ways. Four, or occasionally six replications were made rather than three. The cockroaches were introduced immediately after the jars were prepared for the test. They were exposed to the insecticide in the treated jars for only 1 hour, after which they were removed to clean jars. The conditions of the cockroaches was observed only after 24 hours had elapsed since the initiation of the test.

\section{RECOVERY TESTS}

In order to determine whether "knockdown" equaled "mortality", observations were continued at 24-hour intervals until all the moribund cockroaches died. A fresh piece of potato was placed in each jar at the end of each 24-hour interval.

\section{INSECTICIDES}

Facts about the insecticides used in these tests are given in the tabulation below including names, sources, and dilution information. Table 1 shows the rates of application (in milligrams per square foot) for each concentration of each insecticide.

Bayer 29499 (0,0-dimethyl O-[4-(methylthio)-m-tolyl]phosphorothioate); 25-percent wettable powder from Chemagro Corp., Kansas City, Mo. 
Percent

2.0

1.25

.25

.05

.01

.002
Formulation

$4 \mathrm{gm}$. of 25 percent in $50 \mathrm{ml} . \mathrm{H}_{2} \mathrm{O}$

$10 \mathrm{ml}$. of 2 percent in $6 \mathrm{ml}$. acetone

$2 \mathrm{ml}$. of percent in $14 \mathrm{ml}$. acetone

$1 \mathrm{ml}$. of 1.25 percent in $24 \mathrm{ml}$. acetone

$1 \mathrm{ml}$. of 0.25 percent in $29 \mathrm{ml}$. acetone

$1 \mathrm{ml}$. of 0.05 percent in $24 \mathrm{ml}$. acetone

Chlordane, Entomological Socicty of America Standard, from the Armed Forces Pest Control Board

Perceul

1.0

1
Formulation

$1 \mathrm{ml}$. in $99 \mathrm{ml}$. acetone

$1 \mathrm{ml}$. of 1 percent in $9 \mathrm{ml}$. acetone

TABLE 1.-Percenlage rates of application of insecticides ${ }^{1}$

\begin{tabular}{l|c|c|c|c|c|c|c}
\hline \multicolumn{1}{c|}{ Insecticide } & 0.002 & 0.01 & 0.05 & 0.1 & 0.15 & 0.25 & 1.25 \\
\hline Bayer 20493 & 0.2 & 1 & 5 & - & - & 25 & 125 \\
Chlordane & - & - & - & $10^{2}$ & - & - & - \\
Diazinon & -2 & 8 & 5 & - & - & 26 & 132 \\
Dieldrin & - & - & $5^{2}$ & - & - & - & - \\
Lindane & - & - & $5^{2}$ & - & - & - & - \\
Malathion & 1.2 & 6 & $10^{2}$ & 18 & 30 & 134 \\
Synergized malathion & - & 1.2 & 6 & - & 18 & 30 & 134 \\
\hline
\end{tabular}

1 Rates expressed in milligrams per square foot; estimated inner surface area of the pint jar: $0.25 \mathrm{ft} .^{2} ; 2.5 \mathrm{ml}$. insecticide formulation in each jar.

2 These approximations are given in (1). Figures of 16 for chlordane and 12 for malathion are more accurate than the given figures. The figures for lindane and dieldrin are accurate as given in ( 1 .

Diazinon, 25-percent emulsion from a local pest-control operator

Percemu

1.25

.25

.05

.01

.002
Formulation

$2 \mathrm{ml}$. of 25 percent in $38 \mathrm{ml}$. acetone

$4 \mathrm{ml}$. of 1.25 percent in $16 \mathrm{ml}$. acetone

$1 \mathrm{ml}$. of 1.25 percent in $24 \mathrm{ml}$. acetone

$2 \mathrm{ml}$. of 0.05 percent in $12 \mathrm{ml}$. acetone

$1 \mathrm{ml}$. of 0.05 percent in $24 \mathrm{ml}$. acetone

Dieldrin, Entomological Society of America Standard, from the Armed Forces Pest Control Board

Percent

1.0

.05

\section{Formulation}

$0.5 \mathrm{gm}$. in $50 \mathrm{ml}$. acetone

$1 \mathrm{ml}$. of 1 percent in $19 \mathrm{ml}$. acetone 
Lindane, Entomological Society of America Standard, from the Armed Forces Pest Control Board

Dilutions the same as for dieldrin

Malathion (premium grade), 95 percent from the Armed Forces Pest Control Board

$\begin{array}{ll}\text { Percent } & \text { Formulation } \\ 1.25 & 1 \mathrm{ml} \text {. of } 95 \text { percent in } 75 \mathrm{ml} \text {. acetone } \\ 1.0 & 1 \mathrm{ml} \text {. of } 95 \text { percent in } 99 \mathrm{ml} \text {. acetone } \\ .25 & 4 \mathrm{ml} \text {. of } 1.25 \text { percent in } 16 \mathrm{ml} \text {. acetone } \\ .15 & 2 \mathrm{ml} \text {. of } 1.25 \text { percent in } 14.6 \mathrm{ml} \text {. acetone } \\ .1 & 1 \mathrm{ml} \text {. of } 1 \text { percent in } 9 \mathrm{ml} . \text { acetone } \\ .05 & 1 \mathrm{ml} \text {. of } 1.25 \text { percent in } 24 \mathrm{ml} \text { acetone } \\ .01 & 3 \mathrm{ml} \text {. of } 0.05 \text { percent in } 12 \mathrm{ml} \text {. acetone }\end{array}$

Malathion, 21.053 percent, and pyrethrum, 4.23 percent, synergized with 1.25-percent piperonyl butoxide, from Fairfield Chemical Division, Baltimore, $M d$.

Percent

Formulation

1.25

$2 \mathrm{ml}$. of 21 percent in $31.7 \mathrm{ml}$. acetone

Other dilutions used were the same as for nonsynergized malathion.

\section{RESULTS AND DISCUSSION}

The temperature under which all the tests in this report were performed varied from $77^{\circ}$ to $86^{\circ} \mathrm{F}$. and the relative humidity varied from 42 to 100 percent. Of some 310 cockroaches used as controls, none died or became moribund in up to 24 or 48 hours, but 1 died between 48 and 72 hours.

\section{KNOCKDOWN TESTS}

According to information given by the Armed Forces Pest Control Board (1), resistance of male German cockroaches is indicated if the LT50 is greater than 7 hours with chlordane or malathion, more than 6 hours with dieldrin, or more than 1 hour with lindane. By this standard the strain of the German cockroaches tested in the present study is resistant to chlordane (LT50 > 72), lindane (LT50 = 7), and dieldrin (LT50 > 72). These cockroaches were apparently still susceptible to malathion, since the LT50 was 1.75 hours. Similar results were secured using female cockroaches: Chlordane (LT50 > 72), lindane (LT50 =6), dieldrin (LT50 > 72), and malathion (LT50 = 1.25).

\section{LETHAL CONCENTRATION TESTS}

In the LT50 test, moribund knockdown cockroaches are, in effect, equated with dead cockroaches. Should this lead be followed when estimat- 
ing the LC50 or LC90? More pointedly the question is, "Do moribund roaches recover?." Since this can be answered only by observation, most of the cockroaches that turned up moribund in these tests were observed at 24-hour intervals until all were dead. Most of these morbid cockroaches died by the end of 48 hours, but a tenacious few died only shortly before the 120 -hour observation. Not one of some 300 cockroaches observed in this way, survived its morbid condition. It was therefore concluded that, in this study, moribund cockroaches could be considered dead, and that "Dead plus moribund" figures should be used to estimate the LT50's and LC90's (table 2).

Of the four insecticides used in the LT:50 tests, only malathion was used in the lethal concentration tests. The LT:50 test demonstrates clearly that

TABLE 2.-Estimaled LC60's and LC90's for male and female German cockroaches in Puerto Rico

\begin{tabular}{|c|c|c|c|c|c|c|c|c|}
\hline \multirow{3}{*}{ Insecticide } & \multicolumn{4}{|c|}{ Dead } & \multicolumn{4}{|c|}{ Dead plus moribund } \\
\hline & \multicolumn{2}{|c|}{ LC50 } & \multicolumn{2}{|c|}{ LC90 } & \multicolumn{2}{|c|}{ LC50 } & \multicolumn{2}{|c|}{ LC90 } \\
\hline & Male & Female & Male & Female & Male & Female & Male & Female \\
\hline Bayer 29493 & 0.02 & 0.04 & 0.07 & 0.14 & 0.007 & 0.012 & 0.016 & 0.024 \\
\hline Diazinon & .05 & .2 & .2 & 2.0 & .02 & .01 & .05 & .02 \\
\hline Malathion & 1.25 & $>1.25$ & $>1.25$ & $>1.25$ & .13 & .08 & .35 & .2 \\
\hline $\begin{array}{l}\text { Synergized } \\
\text { malathion }\end{array}$ & .15 & .25 & .3 & .35 & .07 & .1 & .12 & .15 \\
\hline
\end{tabular}

the local strain of the German cockroach is susceptible to malathion. Estimated LC50's and 90's, based on dead-plus-moribund figures, bear out this conclusion. However, considering only the LC50's and 90's based on figures for dead cockroaches, one might easily be led to believe that these cockroaches are progressing toward resistance to malathion, if not already tolerant of it.

It appears to the present writer that LC50's and 90's based on dead-plusmoribund figures are more reliable, i.e., reflect more accurately the actual status of the local strain of the German cockroach with regard to insecticide resistance-susceptibility, than do LC50's and 90's based solely on dead figures.

Bayer 29493 (table 3), an experimental compound, and diazinon (table 3 ), a product widely used by local pest-control operators, gave comparable and very satisfactory results against the cockroaches (table 3). Synergized malathion was also very effective (table 3), only slightly less so than Bayer 29493 and diazinon. Judging from the greater effectiveness of synergized 
malathion as compared to regular malathion, the addition of a little pyrethrum and piperonyl butoxide is certainly worthwhile.

\section{SUMMARY}

Adult males and females of a strain of Blattella germanica cultured from collections made in the School of Medicine, San Juan, P.R., were tested for insecticide resistance-susceptibility. According to the LT50 test these cockroaches demonstrated resistance to chlordane ( $\sigma^{7}$ and ㅇ LT $50>72$ ), lindane $\left(\sigma^{7}\right.$ LT:50 = 7); $\left.\%, 6\right)$, and dieldrin $\left(\sigma^{7}\right.$ and $\&$ LT:50 > 72), but were susceptible to malathion $\left(\sigma^{\top}\right.$ LT $50=1.75 ;$;, 1.25$)$. Lethal concen-

TABLe 3.-Averaged results of 1-hour exposure of a Puerto Rican strain of Blattella germanica to 5 -percent concentrations of several insecticides ${ }^{1}$

\begin{tabular}{|c|c|c|c|c|c|c|c|c|c|c|c|c|c|}
\hline \multirow[b]{2}{*}{ Insecticide } & \multirow[b]{2}{*}{ Sex } & \multicolumn{2}{|c|}{0.002} & \multicolumn{2}{|c|}{0.01} & \multicolumn{2}{|c|}{0.05} & \multicolumn{2}{|c|}{0.15} & \multicolumn{2}{|c|}{0.25} & \multicolumn{2}{|c|}{1.25} \\
\hline & & Dead & $\begin{array}{l}\bar{t} \\
\dot{t}\end{array}$ & Dead & $\bar{z}$ & Dead & $\bar{a}$ & Dead & $\vec{a}$ & Dead & $\overline{⿱ 亠 䒑}$ & Dead & 辛 \\
\hline \multirow[t]{2}{*}{ Bayer 29493} & $\sigma^{2}$ & 5 & 5 & 22 & 55 & 22 & 100 & 一 & 一 & 100 & 100 & 90 & 100 \\
\hline & $q$ & 0 & 0 & 3 & 3 & 38 & 100 & - & 一 & 100 & 100 & 100 & 100 \\
\hline \multirow[t]{2}{*}{ Diazinon } & $0^{7}$ & 0 & 0 & 37 & 58 & 32 & 87 & - & - & 68 & 100 & 100 & 100 \\
\hline & q & 0 & $\mathbf{0}$ & 10 & 42 & 20 & 100 & - & - & 30 & 100 & 95 & 100 \\
\hline \multirow[t]{2}{*}{ Malathion } & $\sigma^{\pi}$ & 一 & 一 & 0 & 0 & 0 & 2 & 12 & 65 & 10 & 72 & 22 & 100 \\
\hline & 우 & - & - & 5 & 5 & 2 & 8 & 5 & 88 & 25 & 90 & 10 & 100 \\
\hline \multirow{2}{*}{$\begin{array}{l}\text { Synergized } \\
\text { malathion }\end{array}$} & $0^{7}$ & - & 一 & 0 & 0 & 7 & 13 & 55 & 98 & 62 & 100 & 100 & 100 \\
\hline & 9 & - & - & 0 & 0 & 0 & 0 & 22 & 75 & 32 & 100 & 100 & 100 \\
\hline
\end{tabular}

${ }^{1}$ All figures in this table are percentages: averages are based on observations made 24 hours after exposure; $\mathrm{D}+\mathrm{M}=$ dead plus moribund.

trations at the 50- and 90-percent levels, estimated on the basis of combined counts of "dead" and "moribund" insects, indicated that the cockroaches are susceptible to the following insecticides, listed in decreasing order of effectiveness: Bayer 29493 ( $\sigma^{7}$ LC50 $=0.007 ;$ \& , 0.012; $\sigma^{\top}$ LC90 $=0.016$; ㅇ, 0.024), diazinon ( $\sigma^{\top} \mathrm{LC} 50=0.02 ; \%, 0.01 ; \sigma^{7} \mathrm{LC} 90=0.05 ; \%, 0.02$ ), synergized malathion ( $\sigma^{\top}$ LC50 $=0.07 ;$ \% , $0.1 ; \sigma^{\top}$ LC90 $=0.12 ; \%, 0.15$ ), and malathion ( $\sigma^{7}$ LC50 $=0.13 ;$ ㅇ, $0.08 ; \sigma^{7}$ LC90 $=0.35 ;$ \% , 0.2).

\section{RESUMEN}

Pruebas de resistencia y susceptibilidad a insecticidas se llevaron a cabo en adultos machos y hembras de una cepa de Blattella germanica criados en el laboratorio, de especímenes recogidos en la Escuela de Medicina en San 
Juan, Puerto Rico. Estas cucarachas, de acuerdo con la prueba de LT50, demostraron tener resistencia a clordano $\left(\sigma^{7}\right.$ y $\&$ LT50 $\left.>72\right)$, lindano $\left(\sigma^{7}\right.$ LT50 = 7; ㅇ , 6), y dieldrin $\left(\sigma^{7} \mathrm{y}\right.$ ㅇ LT50 > 72), pero ser susceptibles a malathion ( $\sigma^{7}$ LT50 $=1.75 ;$ ㅇ 1.25). Concentraciones letales a un nivel de 50 a 90 por ciento, calculadas a base de contajes combinados de especímenes "muertos" y "moribundos," demostraron que las cucarachas son susceptibles a los siguientes insecticidas, colocados en orden descendente de efectividad: Bayer 29493 ( $\sigma^{7}$ LC50 $=0.007 ;$; , 0.012; $\sigma^{7}$, LC90 $=0.16$; ㅇ, 0.024), diazinon ( $\sigma^{7}$ LC50 $=0.02: \uparrow 0.01 ; \sigma^{7} \mathrm{LC} 90=0.05 ;$ \% , 0.02), malathion sinergizado ( $\sigma^{7} \mathrm{LC} 50=0.07 ; \%, 0.1 ; \sigma^{7} \mathrm{LC} 90=0.12 ;$ ㅇ , 0.15), y malathion ( $\sigma^{7} \mathrm{LC} 50=0.13$; 우, $0.08 ; \sigma^{7} \mathrm{LC} 90=0.35 ;$ ㅇ, 0.2 ).

\section{LITERATURE CITED}

1. Armed Forces Pest Control Board, Methods for Determining the Susceptibility or Resistance of Insects to Insecticides, Technical Information Mem. 3 pp. 1-34, 1959.

2. Grayson, James McD., Insecticidal resistance and control in cockroaches, Misc. Pub. Entomol. Soc. Am. 2 (1) 55-8, 1960.

3. Roth, L. M., and Willis, E. R., The medical and veterinary importance of cockroaches, Smithson. Misc. Coll. 134 (10) 1-147, 1957. 